\title{
Pemamfaatan Teknologi Informasi dalam Optimalisasi Pelayanan Publik dan Potensi Desa
}

\author{
Oleh: Muhammad Rais Rahmat Razak \\ Hasil Seminar Kegiatan Pengabdian Magang Tahun 2018. \\ Lembaga Kerjasama dan Kantor Urusan Internasional (LK2UI) \\ Prodi Ilmu Pemerintahan. Stisip Muhammadiyah Rappang \\ mraisrahmat@gmail.com
}

\section{PENDAHULUAN}

\section{A. Latar Belakang}

Sekolah Tinggi Ilmu Sosial Ilmu Politik (STISIP) Muhammadiyah Rappang berlokasi di jalan angkatan 45 Lotang Salo Kelurahan Maccorawalie Kecamatan Panca Rijang Kabupaten Sidenreng Rappang. Perguruan Tinggi Muhammadiyah ini mengelola dua (2) program studi strata satu yakni Ilmu Pemerintahan dan Administrasi Negara dan satu (1) program studi strata dua yakni Magister Administrasi Publik. Menurut data kemahasiswaan pada Tahun akademik 2017/2018 STISIP Muhammadiyah Rappang memiliki jumlah mahasiswa Sekitar 1014 dan didukung oleh beberapa lembaga atau unik kerja seperti Lembaga Penelitian dan Publikasi Ilmiah (LP2I), Lembaga Pengabdian pada Masyarakat (LPPM), Lembaga Penjaminan Mutu Internal (LPMI) serta Lembaga Kerjasama dan Kantor Urusan Internasional (LKKUI).

Lembaga Kerjasama Dan Kantor Urusan Internasional (LKKUI) mengakomodir setiap persoalan terkait dengan penelitian dan pengabdian masyarakat.Seperti kegiatan Magang dimana kegiatan ini menekankan mahasiswa dalam kegiatan pengabdian masyarakatnya lebih pada proses pemamfaatan teknologi dan potensi desa ,seperti kegiatan magang yang baru saja dilaksanakan oleh LKKUI STISIP Muhammadiyah Rappang dengan tema "Pemamfaatan teknologi informasi 
dalam optimalisasi pelayanan publik dan potensi desa". Kegiatan ini melibatkan kurang lebih 190 Mahasiswa STISIP Muhammadiyah Rappang yang terbagi menjadi 10 Posko setiap Desa di Dua Kabupaten yakni Kabupaten Sidenreng Rappang dan Kabupaten Enrekang.

Kegiatan magang ini sangat penting untuk membantu mahasiswa guna mengimplementasikan ilmu pengetahuan yang diperoleh di kampus sebagai gambaran dalam dunia kerja yang sebenarnya. Di samping itu kegiatan magang ini juga sebagai bentuk pengabdian masyarakat bagi dosen yang bersangkutan dan dapat menambah wawasan mahasiswa dalam berpola pikir dan bertindak dalam memecahkan setiap masalah yang dihadapi di lingkungan kerja. Selama ini mahasiswa hanya terbiasa memecahkan masalah di lingkungan kampus saja tanpa tahu kondisi riil yang terjadi sebenarnya dalam dunia kerja dan sesuai dengan tema pelaksanaan magang tahun ini, mahasiswa dituntut untuk lebih meningkatkan pelayanan publik dan potensi yang ada di 10 Desa yang ada di Kabupaten Sidenreng Rappang dan Kabupaten Enrekang, khususnya di Desa Sipodeceng Kecamatan Baranti Kabupaten Sidenreng Rappang. Kegiatan magang angkatan II di Desa Sipodeceng, juga menindaklanjuti atau melakukan desiminasi atas hasil pengabdian pada KKLP angkatan XVI yang dilaksanakan pada tahun 2017 di Desa Sipodeceng. beberapa catatan hasil KKLP di Sipodeceng menurut Razak, M.R.R (2017) sebagai berikut:

- Masyarakat Sipodeceng memiliki minat dan potensi untuk mengembangkan usaha-usaha kreatif, namun pemasaran kurang sehingga diperlukan pembinaan lebih lanjut.

- Banyak potensi usaha kreatif lain yang memerlukan pembinaan agar dapat menjadi salah satu penopang ekonomi masyarakat desa.

- Dibutuhkan model unit usaha yang dapat memotivasi dan menggerakkan usahausaha kreatif agar berkembang dalam bentuk sistem pemasaran berbasis jaringan yang dapat membangun sinergitas usaha.

- Badan Usaha Milik Desa (Bumdes) perlu diberdayakan dan dikelola dengan baik agar dapat menjadi penggerak ekonomi kerakyatan di Desa Sipodeceng. 
Untuk mencapai hal tersebut diatas, mahasiswa magang turun ke lapangan selama satu bulan untuk melakukan pendataan dan melihat potensi-potensi yang ada di desa secara langsung sehingga data yang di hasilkan akurat dan bisa di mamfaatkan oleh desa itu sendiri.

\section{B. Rumusan Masalah}

Berdasarkan latar belakang tersebut diatas, maka kegiatan pengabdian masyarakat dalam bentuk Pemagangan Mahasiswa di Desa Sipodeceng akan mengambil tema pada "Pemamfaatan teknologi informasi dalam optimalisasi pelayanan publik dan potensi desa”. Kegiatan Magang akan fokus pada pendataan terhadap potensi desa dan penyebarluasan informasi desa dengan menggunakan website Desa Sipodeceng yang akan dibuat.

\section{Tinjauan Pustaka}

\section{Tehnologi Informasi}

Tehnologi Informasi telah menjadi instrumen penting dalam meningkatkan hubungan antara pemerintah dengan khalayak, termasuk juga di dalamnya pemerintah desa, sehingga sudah menjadi keniscayaan bagi setiap daerah ataupun desa untuk meningkatkan kinerja pemerintahaannya dengan memanfaatkan tehnologi informasi. Menurut Lucas:2000, Teknologi Informasi adalah segala bentuk teknologi yang diterapkan untuk memproses dan mengirimkan informasi dalam bentuk elektronis. Dan tidak hanya terbatas pada perangkat keras dan software-nya tapi juga bagaimana mengirim dan menerima informasi. Menurut Martin:1999, Teknologi Informasi tidak hanya terbatas pada teknologi komputer (software \& hardware) yang digunakan untuk 
memproses atau menyimpan informasi, melainkan juga mencakup teknologi komunikasi untuk mengirimkan informasi.

Peran Media massa dalam menkomunikasikan program pemerintah Desa kepada orang banyak atau khalayak seperti apa yang disebutkan oleh, John R. Bittner: "Mass Communication is message communicated throught a mass medium to a large number of people". Komunikasi massa adalah pesan yang dikomunikasikan melalui media massa pada sejumlah besar orang. Berkembangnya tehnologi yang kemudian memberikan pengaruh besar kepada prilaku dan kebiasaan masyarakatnya, hal ini tidak hanya terjadi di kota-kota besar tapi juga di desa-desa. Sehingga untuk meningkatkan pelayanan dan menjalin komunikasi dengan khalayak perlu dibangun komunikasi massa yang berbasis tehnologi, sejalan dengan apa yang disebutkan George Gebner, Adalah produksi dan distribusi berlandaskan teknologi dan lembaga dari arus pesan berkesinambungan serta paling luas dimiliki orang dalam masyarakat industri.

\section{Kebijakan Publik}

Dalam pengelolaan pemerintahan oleh pemerintah, baik di tingkat pusat maupun daerah dibutuhkan berbagai macam bentuk aturan maupun peraturan perundang-undangan yang akan mengatur kepentingan publik untuk kesejahteraan bersama. Kebijakan publik dapat dipahami sebagai sebagai segala sesuatu yang dilakukan ataupun tidak dilakukan oleh pejabat publik, seperti apa yang disebutkan oleh Thomas. R. Dye (1981) “Kebijakan publik dikatakan sebagai apa yang tidak dilakukan maupun apa yang dilakukan oleh pemerintah”.

Hal ini mengandung pengertian bahwa pemerintah memiliki wewenang untuk menggunakan keputusan otoritatif, termasuk keputusan untuk membiarkan sesuatu terjadi, demi teratasinya suatu persoalan publik. Sehingga berbagai kebijakan yang 
dikeluarkan oleh pemerintah pusat maupun pemerintah dibawahnya seyogyanya dapat cepat dikomunikasikan ke khalayak.

Kebijakan juga harus memperhatikan nilai-nilai social budaya yang berkembang di masyarakat karena sebuah kebijakan membutuhkan partisipasi yang memperhatikan fakator lingkungan tertentu seperti, adanya semangat kebersamaan dan kekeluargaan yang tumbuh dari bawah (bottom up) dan kepercayaan serta keterbukaan (Mustanir, A. \& Razak, M.R.R. (2017).

\section{Desa}

Desa adalah pembagian wilayah admninistratif di Indonesia dibawah kecamatan yang di pimpin oleh kepala desa seperti halnya dengan Desa Sipodeceng dipimpin oleh seorang Kepala Desa. Menurut UU no. 6 tahun 2014, Desa adalah desa dan desa adat atau yang disebut dengan nama lain, selanjutnya disebut Desa, adalah kesatuan masyarakat hukum yang memiliki batas wilayah yang berwenang untuk mengatur dan mengurus urusan pemerintahan, kepentingan masyarakat setempat berdasarkan prakarsa masyarakat, hak asal usul, dan/atau hak tradisional yang diakui dan dihormati dalam sistem pemerintahan Negara Kesatuan Republik Indonesia.

Dalam pembangunan desa, pembuatan perencanaan berbasis partisipatif dengan dukungan data potensi desa yang akurat akan memudahkan pemerintah desa dalam memajukan dan mensejahterakan warganya. Perencanaan adalah proses menyusun langkahlangkah dan tahapan yang akan dikerjakan oleh pemerintah desa dalam rangka menjawab berbagai kebutuhan masyarakat, untuk mencapai suatu tujuan tertentu. Perencanaan desa yang baik dapat dipandang sebagai suatu formulasi atau rumusan mengenai aspirasi masyarakat setempat, dalam rangka mencapai suatu kehidupan baru yang lebih baik dan bermakna melalui langkah-langkah pembangunan (Sitonda, R. \& Razak, M.R.R. :2018).

Dengan peroleh data potensi Desa yang akurat, akan memberikan sumber perencanaan 
pembangunan yang baik. Objek dari kegiatan magang akan mengambil lokasi Desa Sipodeceng Kecamatan Baranti kabupaten Sidenreng Rappang.

\section{Maksud dan Tujuan Magang}

Adalah untuk mempersiapkan dan meningkatkan kemampuan serta keterampilan mahasiswa sebelum memasuki dunia kerja. Adapun tujuan pelaksanaan magang adalah sebagai berikut :

Membantu mahasiswa bekerja sambil belajar (learning by doing)

Meningkatkan pemahaman mahasiswa terhadap dunia kerja

Memberikan kesempatan terhadap mahasiswa untuk belajar dari pengalaman mereka (learning from experience) dalam menyongsong era globalisasi

Memperluas pengetahuan mahasiswa dalam memahami situasi, kondisi dalam lingkungan kerja terutamanya dalam pemanfaatan teknologi informasi.

\section{E. SASARAN MAGANG}

Pada dasarnya magang mempunyai tiga kelompok sasaran, yaitu mahasiswa, masyarakat bersama Pemerintah Daerah, dan Perguruan Tinggi. Masing - masing akan memperoleh manfaat dari pelaksanaan magang, Sebagai berikut :

\section{Mahasiswa}

a. Memperdalam pengertian dan penghayatan mahasiswa tentang pemberdayaan masyarakat dan potensi yang ada di desa. 
b. Mendewasakan cara berfikir serta meningkatkan daya penalaran mahasiswa dalam melakukan penelaahan, perumusan dan pemecahan masalah secara pragmatis

c. Memberikan keterampilan kepada mahasiswa untuk melaksanakan pemberdayaan masyarakat.

\section{Perguruan Tinggi}

a. Memperoleh umpan balik sebagai hasil pengintegrasian mahasiswa di tengah-tengah masyarakat, sehingga kurikulum, materi perkuliahan dan pengembangan ilmu yang ada di Perguruan Tinggi dapat disesuaikan dengan tuntutan nyata

b. Memperoleh berbagai kasus yang berharga yang dapat digunakan sebagai contoh dalam memberikan materi perkuliahan dan berbagai masalah untuk pengembangan penelitian

c. Meningkatkan, memperluas dan mempererat kerjasama dengan instansi serta departmen lain melalui rintisan kerjasama dari mahasiswa yang melaksanakan magang di desa masing -masing.

\section{Masyarakat dan Pemerintah Desa}

Mengupayakan perbaikan pengelolaan kehidupan kemasyarakatan baik oleh pemerintah desa maupun partisipasi masyarakat dalam bentuk keikutsertaan dan keterlibatan dalam pembangunan kehidupan masyarakat di desa. 


\section{F. Manfaat Kegiatan}

Program pengabdian masyarakat ini memiliki 3 (Tiga) manfaat berdasarkan klasifikasi kelompok, yaitu;

- Manfaat ke-Dosen Pengabdi. Manfaat yang diperoleh yaitu program ini menjadi sarana untuk melaksanakan salah satu dharma dari caturdharma Perguruan Tinggi yang menjadi kewajiban. Dharma yang dimaksud tersebut adalah dharma pengabdian kepada masyarakat dalam bentuk pemagangan.

- Manfaat ke-Mahasiswa Stisip Muhammadiyah Rappang. Mahasiswa merupakan salah satu unsur perguruan tinggi yang memiliki kewajiban caturdharma sama seperti dosen. Mahasiswa dalam proses memenuhi dharma tersebut tidak lagi membuat program lain, tetapi mereka ikut bergabung dalam program yang telah tersusun secara sistematis ini. Salah satu manfaat mendasar yang diperoleh oleh mahasiswa yaitu mereka dapat meminimalisir anggaran dan waktu yang digunakan.

- Manfaat ke-Pemerintah Desa dan Masyarakat Desa, masyarakat dapat memperoleh manfaat yaitu, tersedia informasi aktual, up to date tentang kondisi dan potensi desa Sipodeceng. Pemerintah Desa dapat memberikan pelayanan lebih mudah ke masyarakat karena adanya ketersediaan informasi dan perangkat lunak dan keras di desa serta dapat diakses dengan mudah oleh masyarakat.

\section{G. Target Luaran}

Luaran yang ditargetkan dalam program ini yaitu hasil pelaksanaan program pengabdian kepada masyarakatn dapat diolah menjadi Laporan Hasil Kegiatan, artikel ataupun jurnal yang dapat dipublikasikan secara luas. 


\section{H. Metode Penerapan}

Metode dalam penerapan program ini disusun secara sistematis, yang bertujuan untuk memaksimalkan jalannya program. Susunan pelaksanaan kegiatan dapat dipahami melalui matriks berikut ini:

\begin{tabular}{|c|c|c|}
\hline No & Jenis Kegiatan & Tujuan \\
\hline 1 & Observasi & $\begin{array}{l}\text { Memperoleh data uptudate terkait proses dan } \\
\text { kondisi serta permasalahan data dan potensi } \\
\text { desa yang dimiliki oleh Desa Sipodeceng. }\end{array}$ \\
\hline 2 & Perencanaan & $\begin{array}{l}\text { Membuat perencanaan program yang cocok } \\
\text { untuk menyelesaikan permasalahan yang } \\
\text { dihadapi. Masalah yang dimaksud adalah } \\
\text { kesimpulan dari hasil observasi dan diskusi } \\
\text { bersama pemerintah desa lewat Focus Group } \\
\text { Discussion (FGD). }\end{array}$ \\
\hline 3 & Pemetaan & $\begin{array}{l}\text { Tahapan ini bertujuan untuk memberikan } \\
\text { kejelasan kepada masing-masing pihak yang } \\
\text { terlibat di dalamnya. }\end{array}$ \\
\hline 4 & Pelaksanaan & $\begin{array}{l}\text { Melakukan pendataan di lapangan dan input } \\
\text { data secara on line dari rumah-rumah } \\
\text { penduduk. }\end{array}$ \\
\hline 5 & Tindak Lanjut & $\begin{array}{l}\text { Menyusun program sebagai tindak lanjut } \\
\text { setelah melakukan pendataan. }\end{array}$ \\
\hline
\end{tabular}




\section{Keterkaitan}

Keterkaitan yang dimaksud dalam program ini yaitu keterkaitan yang terbangun antar setiap kelompok yang terlibat dengan prograam Magang serta hasil dan manfaat dari program ini. Keterkaitan tersebut dapat kita lihat pada gambar berikut ini:

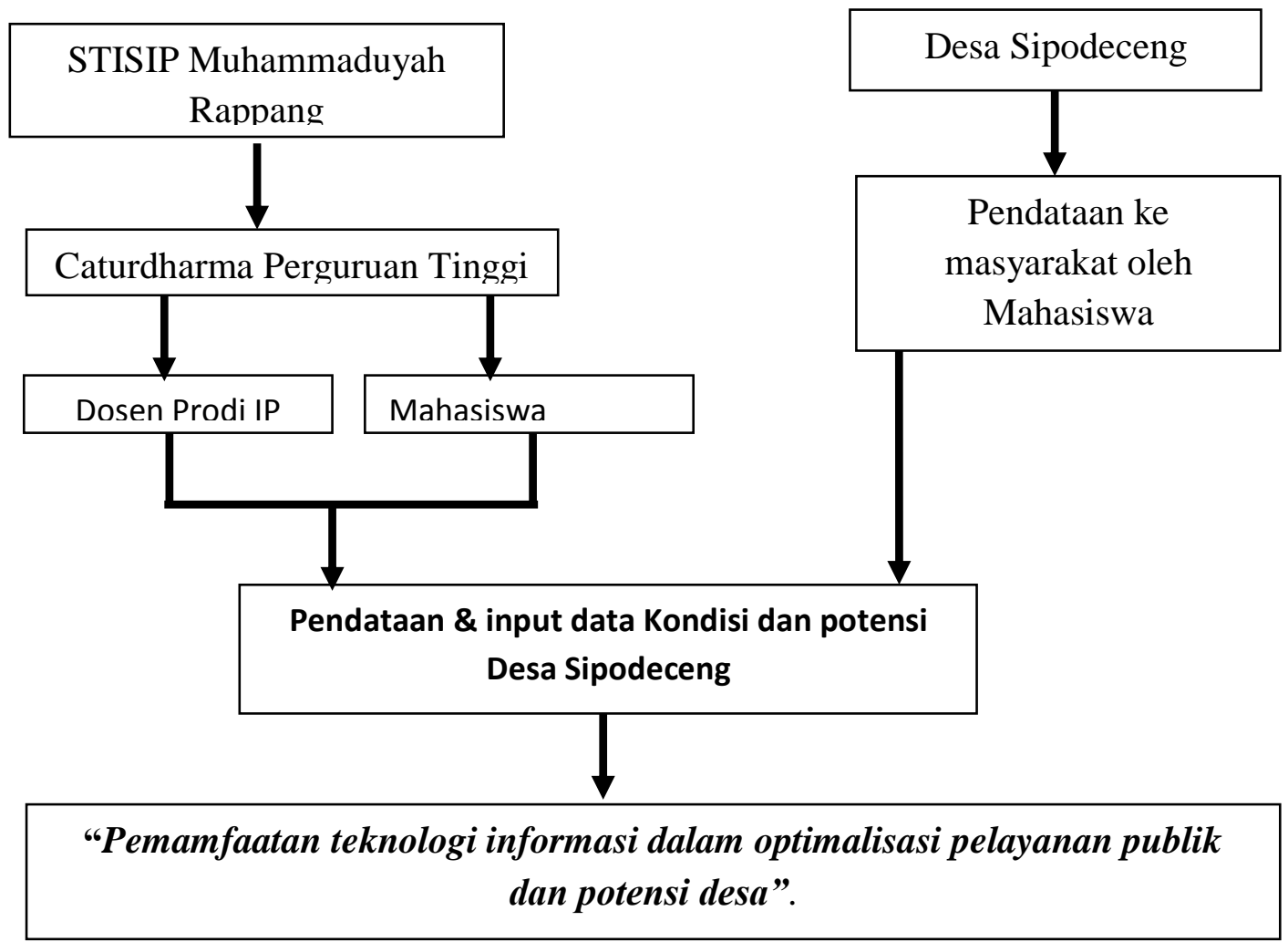




\section{J. Jadwal Pelaksanaan}

\begin{tabular}{|c|c|c|c|c|c|c|c|c|c|c|c|c|c|}
\hline \multirow{2}{*}{ No } & \multirow{2}{*}{ Kegiatan } & \multicolumn{12}{|c|}{ Bulan (2017-2018) } \\
\hline & & 7 & 8 & 9 & 10 & 11 & 12 & 1 & 2 & 3 & 4 & 5 & 6 \\
\hline \multirow{5}{*}{1} & Persiapan Magang & \multicolumn{12}{|c|}{ Persiapan Magang } \\
\hline & Pengajuan UP & & & & & & & & & & & & \\
\hline & Seleksi UP & & & & & & & & & & & & \\
\hline & Keputusan Magang & & & & & & & & & & & & \\
\hline & Penandatangan Kontrak & & & & & & & & & & & & \\
\hline \multirow{5}{*}{2} & Pelaksanaan Pemagangan & \multicolumn{12}{|c|}{ Pelaksanaan Magang } \\
\hline & Pelaksanaan Magang & & & & & & & & & & & & \\
\hline & Laporan Kemajuan & & & & & & & & & & & & \\
\hline & Pemantauan Pelaksanaan Magang & & & & & & & & & & & & \\
\hline & Laporan Hasil Magang & & & & & & & & & & & & \\
\hline \multirow{3}{*}{3} & Pasca Pemagangan & \multicolumn{12}{|c|}{ Pasca Pemagangan } \\
\hline & Seminar Hasil Magang & & & & & & & & & & & & \\
\hline & Publikasi Hasil Magang & & & & & & & & & & & & \\
\hline
\end{tabular}


GAMBARAN LOKASI

\section{A. GAMBARAN UMUM DESA SIPODECENG}

\section{Peta Lokasi Desa Sipodeceng}

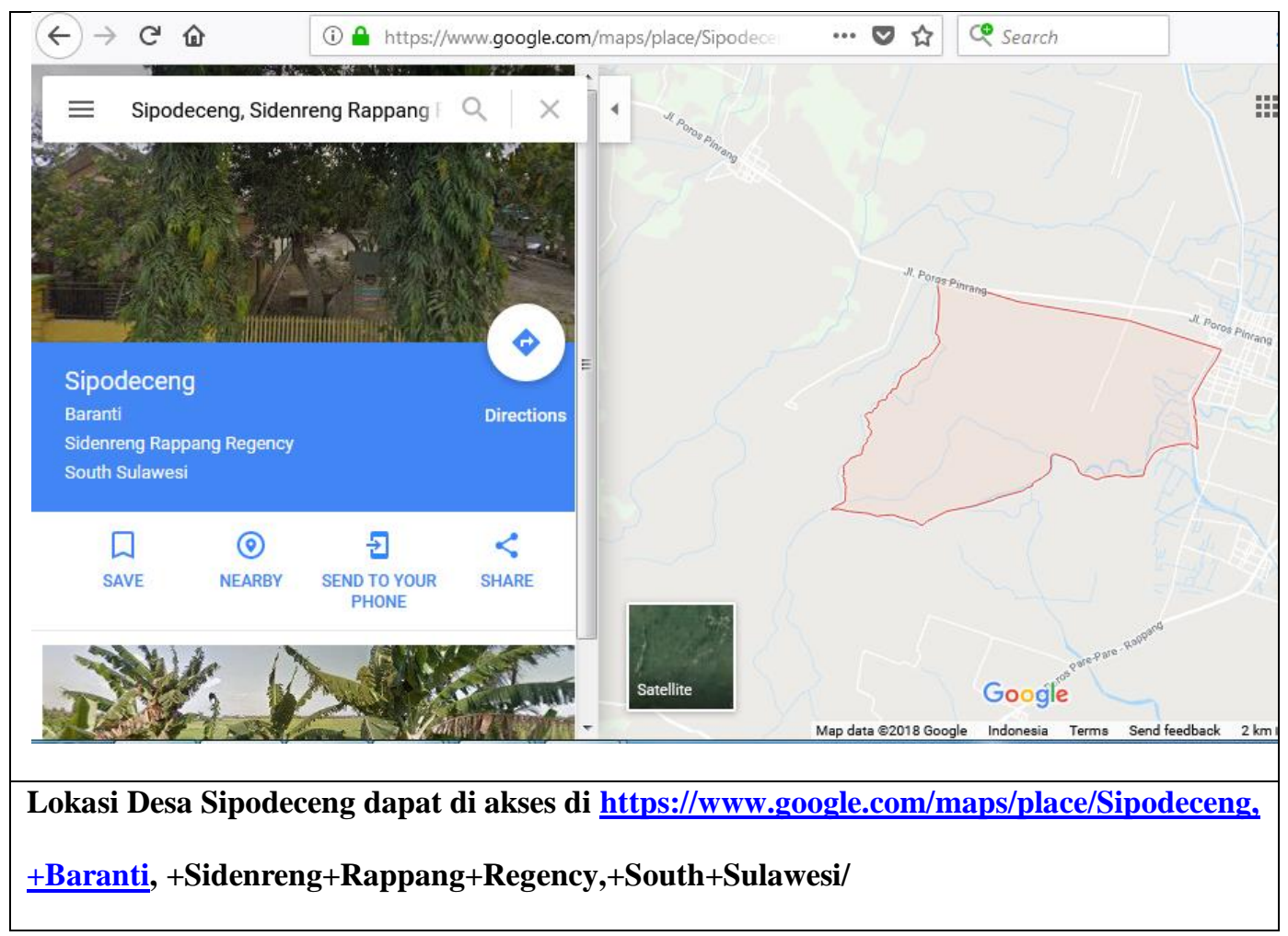

\section{Sejarah Singkat Terbentuknya Desa Sipodeceng}

Ditinjau dari sejarah administrasi wilayah pemerintahan, Desa Sipodeceng merupakan pemekaran dari desa Passeno Kecamatan Baranti dan resmi terbentuk menjadi sebuah Desa dalam lingkungan Kecamatan Baranti Kabupaten Sidenreng Rappang pada tahun 1989 dan terdiri dari tiga Dusun yaitu Dusun Padacenga, Dusun Dea dan Dusun Bonginge. 


\section{Sejarah Pemerintahan Desa Sipodeceng}

Sejarah pemerintahan Desa Sipodeceng sampai sekarang telah dipimpin oleh 4 orang Kepala Desa, dengan urutan sebagai beerikut:

- H. DOHAN

- ISMAAIL

- A. MAPPANGERANG. S.E

- NAMING PALLAJARENG

\section{B. VISI DAN MISI DESA SIPODECENG}

1. Visi

"Mewujudkan Desa Sipodeceng Menjadi Desa Swasembada Pangan"

\section{Misi}

- Menciptakan SDM Yang Beriman dan Bertakwa

- Menciptakan SDM Yang Menguasai Imtek

- Mendorong Lahirnya Industri Berbasis Lokal

- Menciptakan Industri Kreatif Berbahan Baku Lokal Desa

- Memperlancar Perputaran Ekonomi Berbasis Potensi Lokal

- Meningkatkan Partisipasi Masyarakat Dalam Pembangunan 


\section{POTENSI DESA SIPODECENG}

\section{Pertanian}

Ditinjau dari tata guna tanah yang dimanfaatkan oleh penduduk Desa sipodeceng sebagian besar adalah lahan pertanian. Hal ini menunjukkan bahwa masyarakat Desa Sipodeceng Mayoritas bekerja sebagai petani. Tanaman yang dibudi dayakan

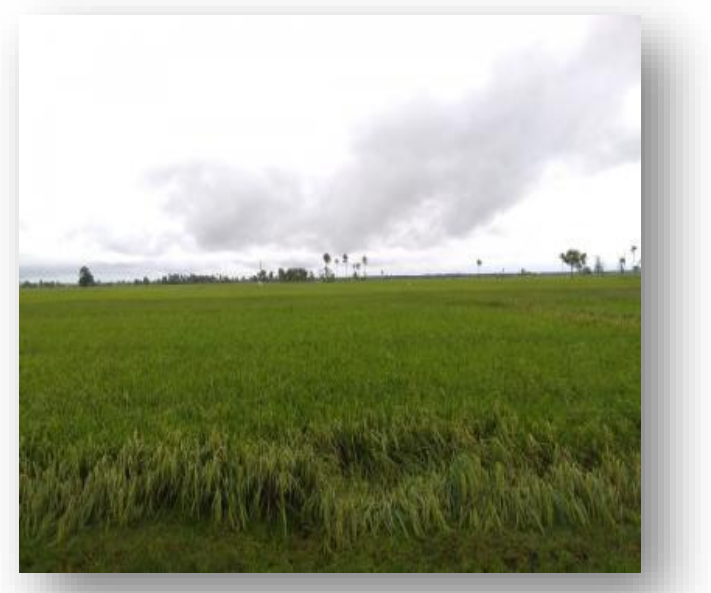
meliputi padi, dan jagung.

Mengingat pemasaran hasil pertanian relatif dekat maka banyak juga penduduk desa yang berprofesi sebagai pedagang sayur mayur. Mereka memperoleh daganganya langsung dari petani yang kemudian dipasarkan ke pasar sentral Baranti, pasar sentral Rappang, Disamping itu ada juga pedagang keliling yang menjual hasil bumi dari Sipodeceng langsung ke konsumen di rumah-rumah penduduk.

\section{Peternakan}

Salah satu mata

pencaharian pokok selain petani di

Desa Sipodeceng yaitu sebagai

peternak ayam ras. Ada 2 orang

yang menjadikan ternak ayam ras

sebagai mata pencaharian pokok.

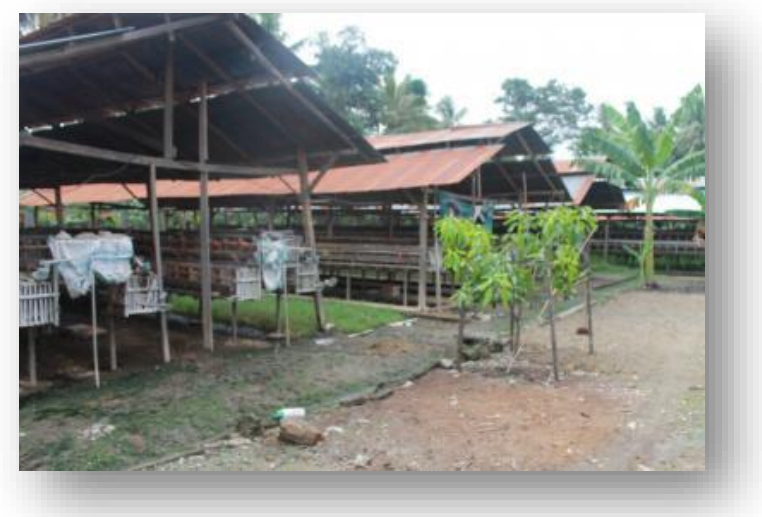

Seperti diketahui ayam ras

berproduksi telur tepat waktu sekitar umur 17-18 minggu. Dan hasil telur dari ternak 
ayam tersebut akan di jual ke sekitaran Masyarakat Desa Sipodeceng dan Desa/Kelurahan di Kecamatan Baranti dan berbagai wilayah sekitar kabupaten seperti Sengkang, Pinrang dan Sidrap itu sendiri. Sedangkan kotorannya tidak dibuang oleh peternak tetapi dimanfaatkan oleh masyarakat sebagai pupuk tanaman dan juga dapat dijual keluar daerah.Jika ayam itu sudah berumur 3-4 tahun atau produksi telurnya sudah menurun maka ayam tersebut dapat dijual untuk kebutuhan sebagai ayam potong.

\section{Perikanan}

Desa Sipodeceng adalah Desa yang mayoritas Masyarakat petani tetapi ada juga masyarakat memanfaatkan lahan kosong untuk di jadikan kolam Ikan dan dimanfaatkan sebagai makanan sehari-hari/sering kali juga dijual ke masyarakat dan pasar.

\section{Sumber Daya Alam}

Tidak hanya sebagai petani, mata pencaharian di Desa Sipodeceng tepatnya di Dusun Bonginge, Selain sebagai petani dan buruh tani, masyarakat desa juga ada yang menjadi pengrajin batu bata. Harga satu buah batu bata yang diproduksi dan dijual
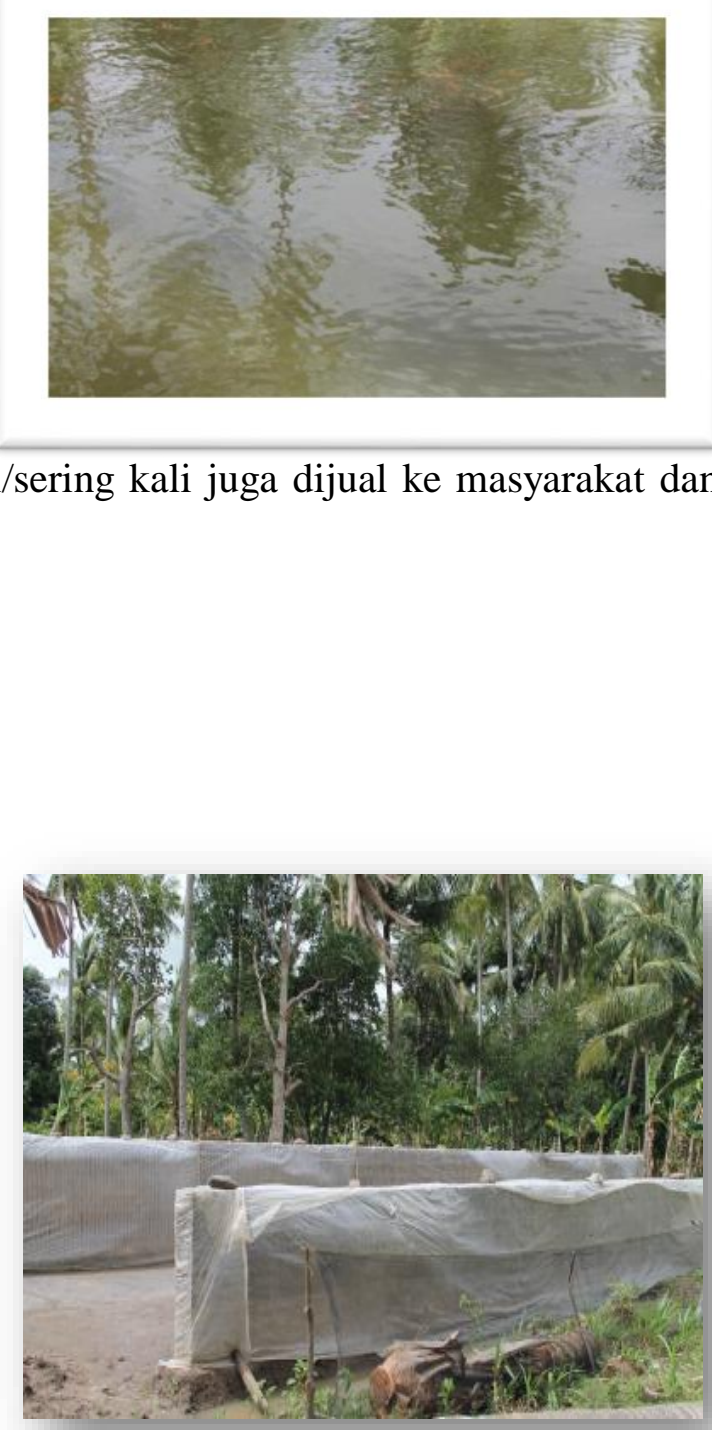
sendiri ini adalah Rp. 600,-/batu bata. Batu bata yang sudah siap untuk dipasarkan tidak 
dikumpulkan disalah satu orang, akan tetapi di jual langsung sendiri ke pelanggan yang datang dan membutuhkan batu bata.

\section{KELEMBAGAAN DESA SIPODECENG}

\section{Struktur Organisasi Badan Permusyawaratan Desa (BPD)}

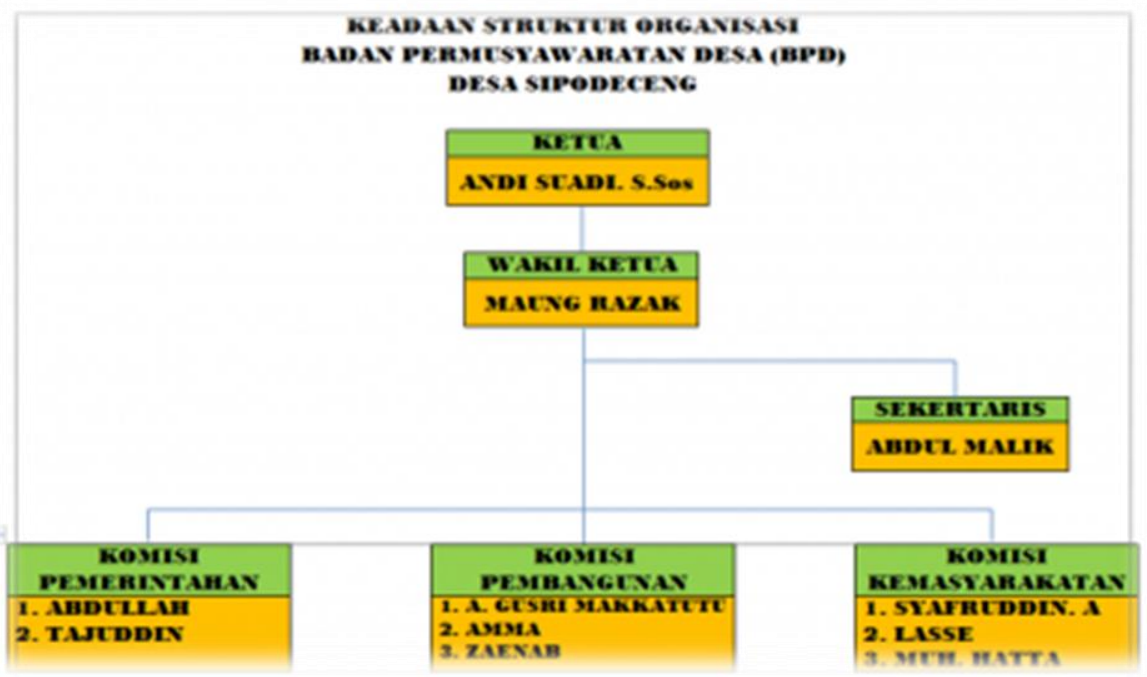

2. Struktur Organisasi Lembaga Ketahanan Masyarakat Desa

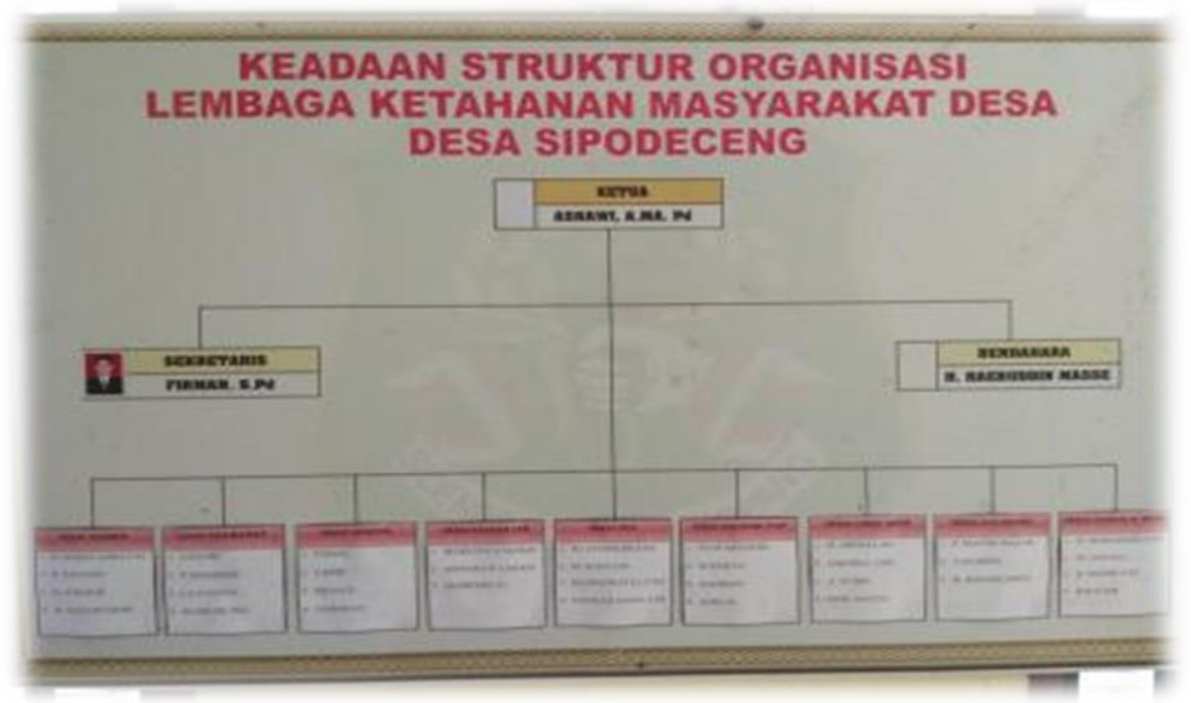




\section{Struktur Organisasi Pokja}

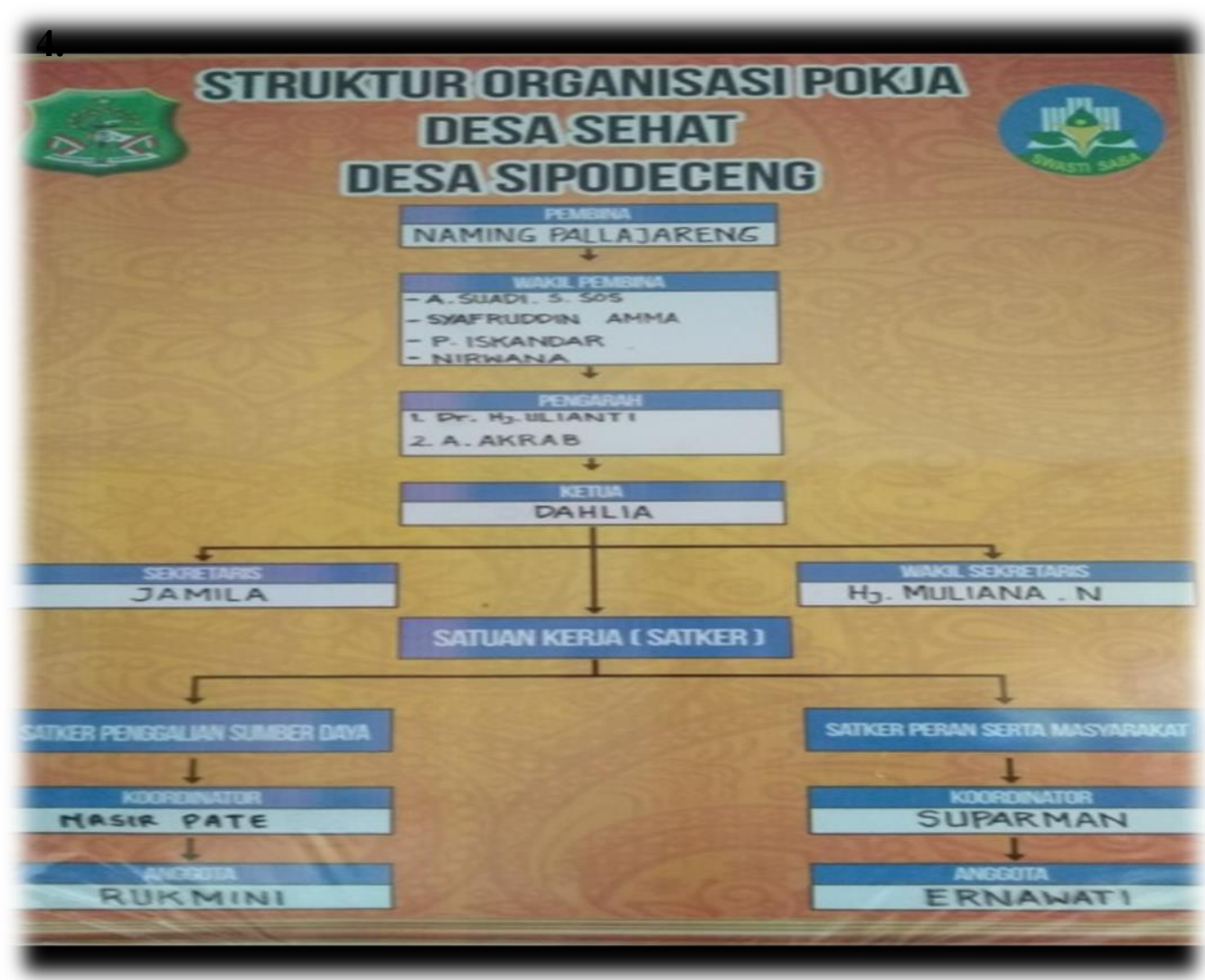

\section{Pembina Kesejahteraan Keluarga (PKK)}

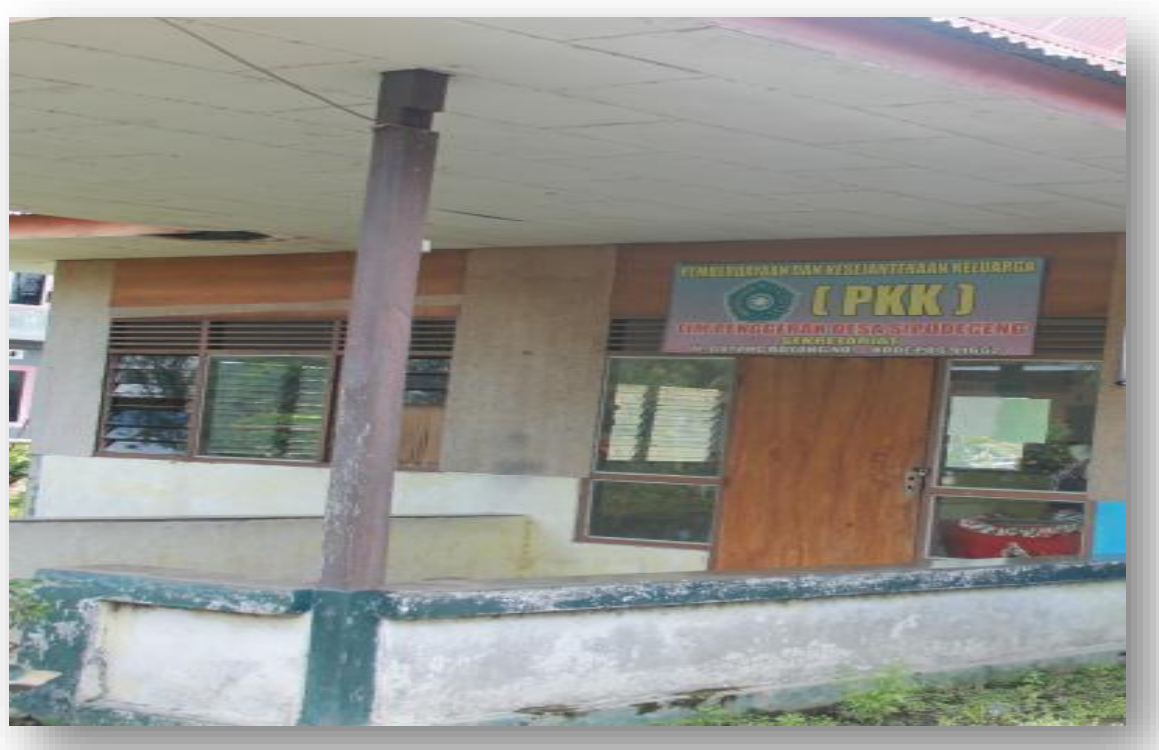




\section{Kelompok Tani}

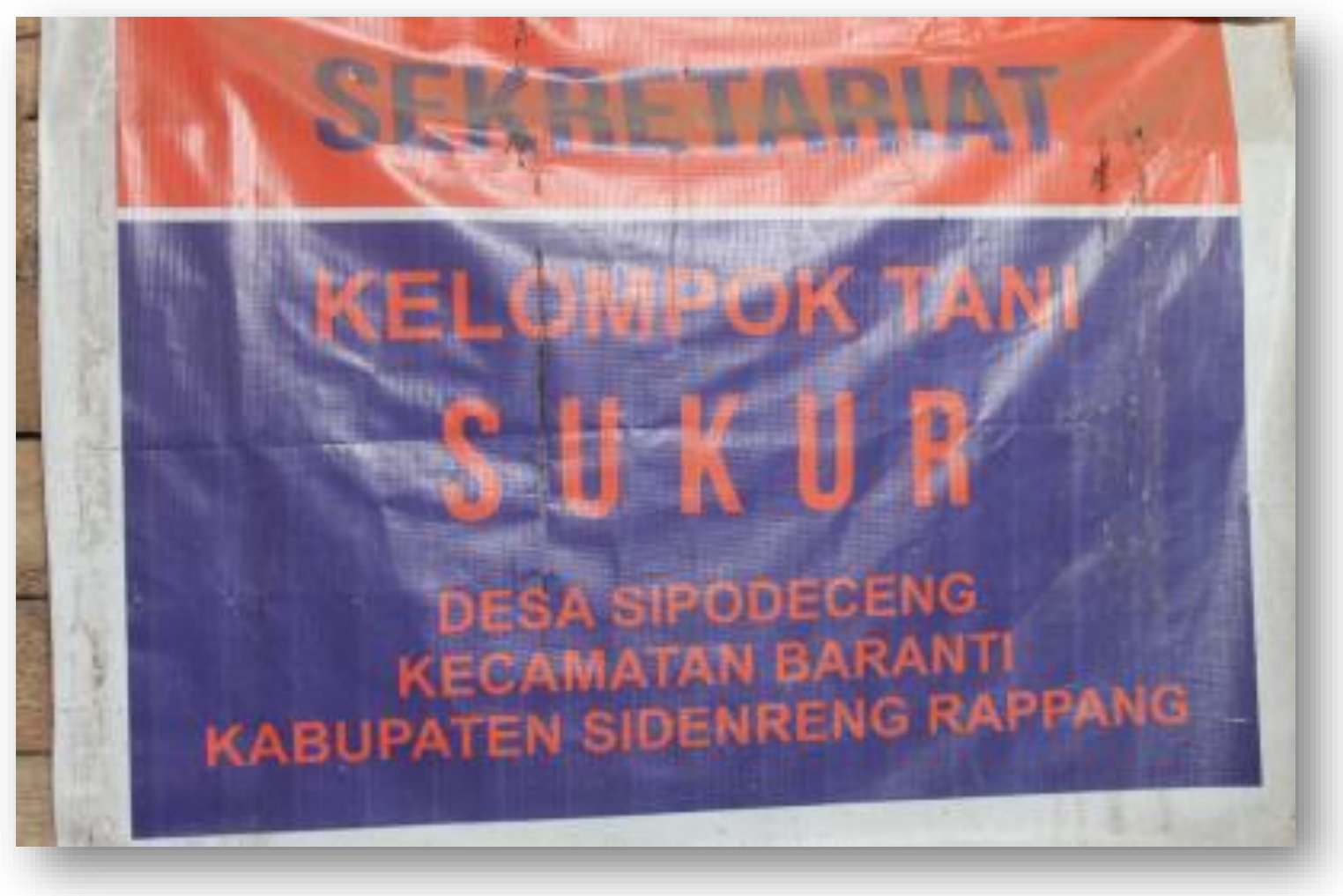


III

\section{GAMBARAN KEGIATAN}

\section{A. Mekanisme Pelaksanaan Kegiatan}

Dari hasil Observasi di beberapa desa termasuk Desa Sipodeceng Kecamatan Baranti, Tim Magang 2018 Stisip Muhammadyah Rappang memberikan ide dasar yakni perlunya Pendataan kondisi dan potensi desa terkini yang bisa diakses real time dan akurat. Hal ini banyaknya hambatan dialami masyarakat dalam mengakses data tentang kondsi dan potensi desa di Kabupaten Sidenreng Rappang dan kabupaten Enrekang. Sehingga Tim mengadakan Workshop internal untuk merumuskan kegiatan kemudian dilanjutkan dengan penentuan desa dan pelaksanaan Forum Group Discussion (FGD) yang menghadirkan kepala-kepala Desa sasaran.

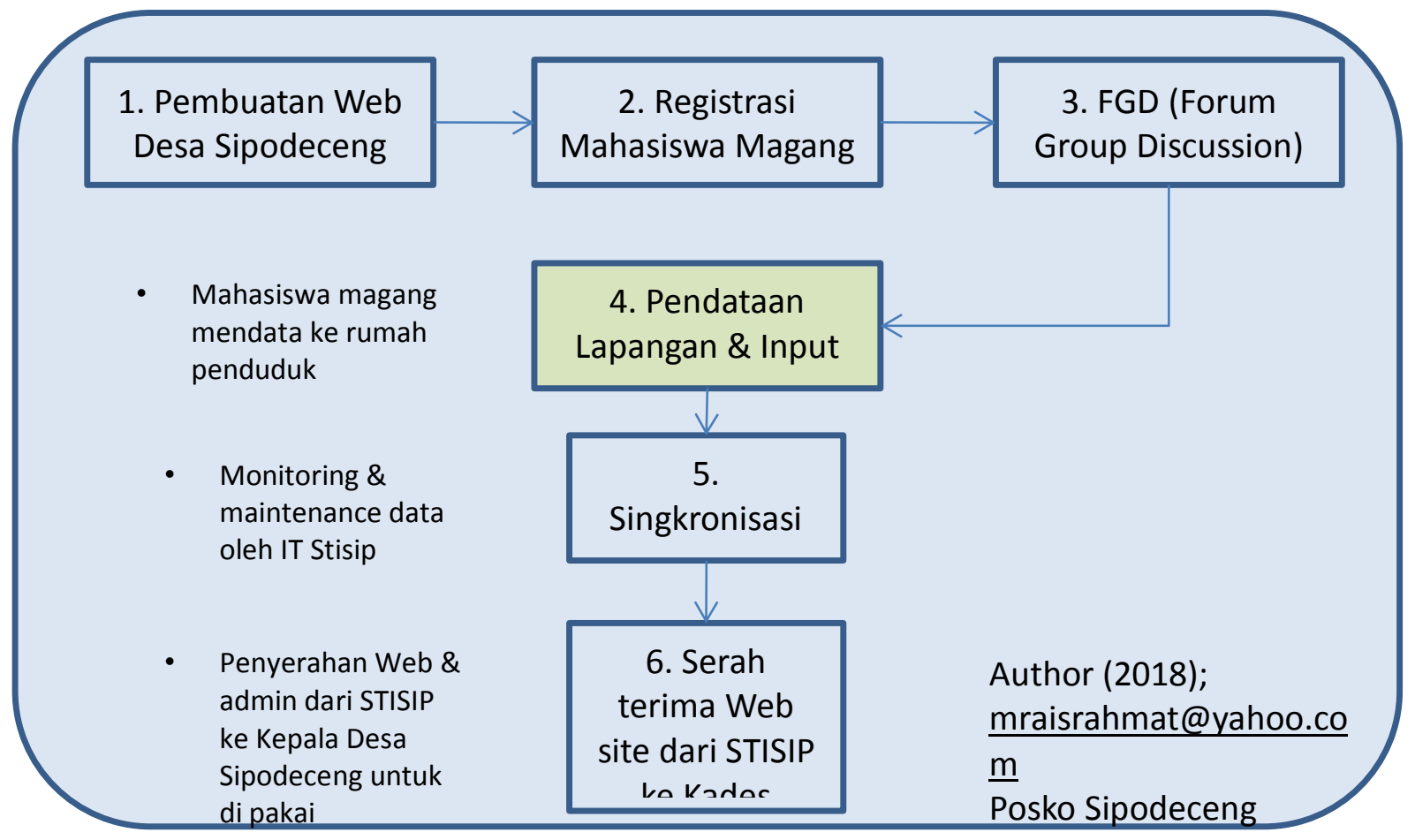




\section{Pembuatan Web Desa}

Data tentang Kondisi Desa dan Potensi desa, masih banyak menggunakan data model lama, sehingga setiap orang yang membutuhkan data tentang Desa Sipodeceng harus datang ke kantor Desa dan belum tentu bisa mendapatkan apa yang dibutuhkan. Data desa sangat diperlukan oleh masyarakat baik pelaku bisnis maupun oleh masyarakat umum. Informasi akurat tentang potensi desa dan data penduduk maupun jenis-jenis pelayanan menjadi hal penting sekarang ini. Warga untuk mendapatkan layanan administrasi standar harus datang ke kantor dan terkadang menunggu lama karena harus menunggu petugas yang sedang bertugas di luar kantor.

Memanfaatkan kemajuan tehnologi informasi dengan menyediakan data dalam bentuk web khusus desa seperti halnya dengan web desa sipodeceng akan menjadi salah satu solusi untuk memberikan kemudahan kepada khalayak dalam mendapatkan akses informasi.

\section{Registrasi Peserta Magang}

Kegiatan Magang Angkatan III Tahun akademik 2017-2018 diwajibkan kepada mahasiswa yang telah menyelesaikan perkuliah-an semister 5 dan penentuan lokasi ditetapkan oleh Lembaga Kerjasama Dan Kantor Urusan Internasional (LKKUI).

\section{Forum Group Discussion (FGD)}

Sebelum pelaksanaan kegiatan magang, dilaksanakan Forum Groud Discussin (FGD) yang terdiri dari Calon Dosen Pembimbing, Kepala Desa rencanaPosko dan TIM Magang yang terdiri dari LK2UI dan bagian IT Stisip Muhammadiyah Rappang. 


\section{Pelaksanaan Pendataan di Lapangan}

Kegiatan Pemagangan di lokasi diawali dengan penerimaan peserta magang oleh kepala desa yang menjadi lokus pendataan. Mahasiswa magang ditempat pada tempat khusus yang telah disiapkan oleh Kepala Desa, dimana mahasiswa magang tinggal selama 30 hari atau satu bulan di desa.

Kegiatan pendataan dilakukan setiap hari dengan mendatangi rumah-rumah penduduk baik yang berpenghuni maupun tidak berpenghuni. Selama di lapangan mahasiswa langsung mendata dan menginput ke website desa.. Untuk mengefektifkan pendataan dapat dibagi atas kelompok-kelompok kecil berdasarkan dusun, RT atau RW, jumlah anggaota disesuaikan dengan beban kerja selama pendataan di lapangan.

\section{Singkronisasi dan publish,}

Proses singkronisasi dilakukan oleh bagian IT Stisip Muhammadiyah Rappang, dengan melakukan monitoring peng-inputan data ke setiap desa. Data yang telah diinput oleh mahasiswa magang di lapangan dapat langsung terpublis ke webside per desa, masing-masing kordinator desa dapat memonitor hasil input dan bila ada hal memerlukan perbaikan dapat berkomunikasi langsung dengan bagian IT. Pada saat progres pendataan mencapai $80 \%$, masing-masing desa dapat melakukan FGD tingkat Desa yang peserta-nya dihadiri oleh Dosen Pembimbing, Kepala Desa, aparat desa, masyarakat, pimpinan Stisip Muhammadiyah Rappang. Sebelum penarikan mahasiswa magang kegiatan didahului dengan kunjungan Pimpinan Stisip Muhammadiyah Rappang.

\section{Serah terima Web}


Setelah peng-inputan data lapangan oleh mahasiswa magang selesai kemudian ditutup dengan FGD seluruh Desa dengan mengambil tempat di Stisip Muhammadiyah Rappang dan diikuti oleh seluruh Mahasiswa Magang, dosen Pembimbing, Pimpinan Stisip serta seluruh Kepala Desa yang menjadi lokasi penempatan Magang.

Website masing-masing desa diserahkan kepada Kepala Desa untuk selanjutnya diserahkan kepada operator masing-masing desa untuk menjadi Administrator website desa.

\section{B. Pelaksanaan Magang}

Pelaksanaan magang dengan tema "Pemamfaatan teknologi informasi dalam optimalisasi pelayanan publik dan potensi desa”. Menekankan pada proses pengambilan data secara langsung ke masyarakat kemudian diinput secara on line ke dalam sistem informasi tehnologi. Ketersediaan perangkat komputer dan sistem komunikasi di kantor Desa sipodeceng serta menyebar pemakaian alat komunikasi berbasis android, merupakan modal dasar dalam mengoptimalkan pemanfaatan informasi tehnologi di desa.

\section{Pembuatan Website Desa}

Sebelum pelaksanaan magang dalam bentuk pendataan kondisi penduduk desa di setiap rumah Tim IT Stisip Muhammadiyah Rappang telah menyiapkan website desa terintegrasi dengan website http://stisimrappang@ac.id yang merupakan web resmi Stisip Muhammadiyah Rappang. 

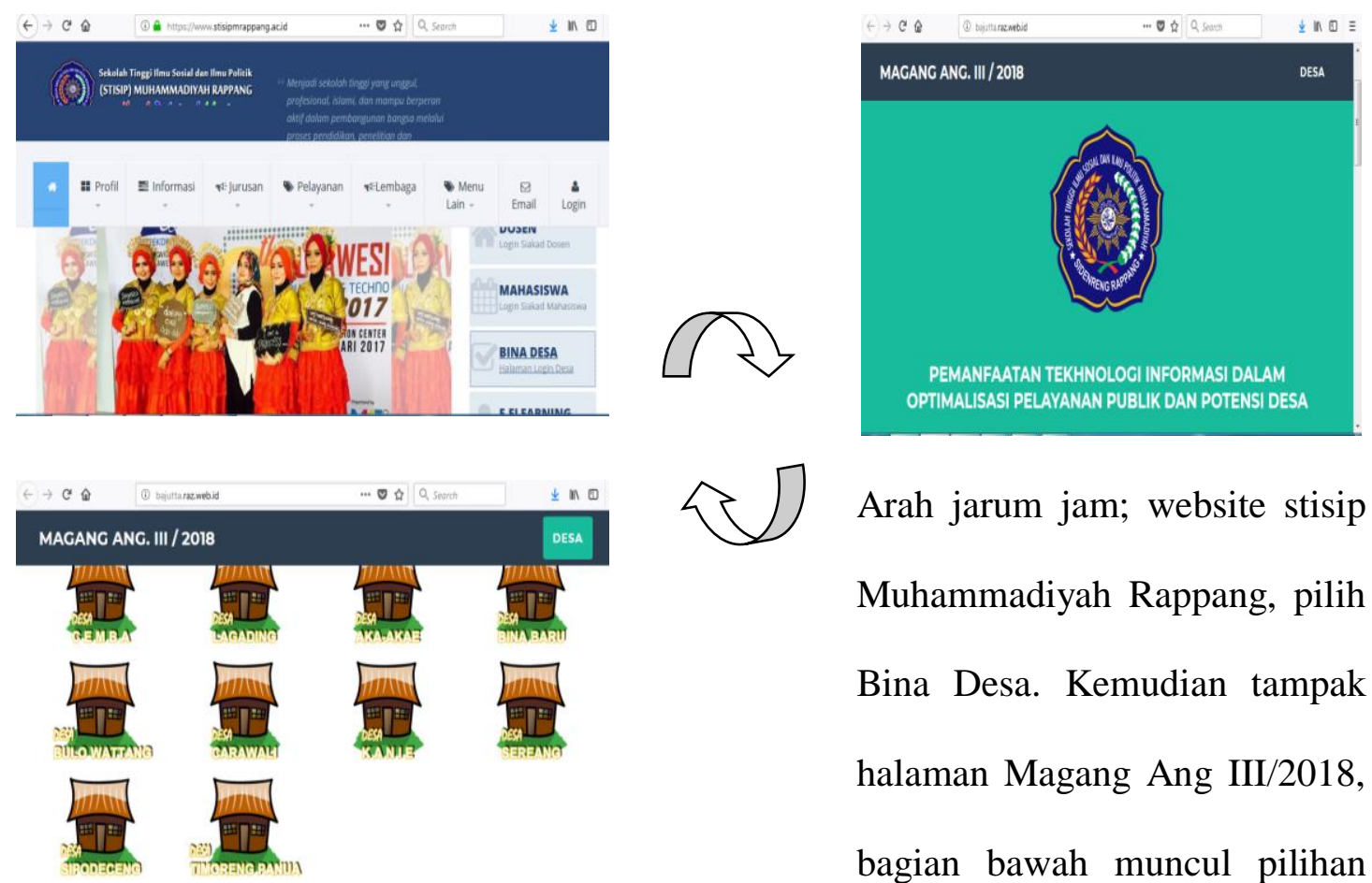

Arah jarum jam; website stisip

Muhammadiyah Rappang, pilih

Bina Desa. Kemudian tampak

halaman Magang Ang III/2018, bagian bawah muncul pilihan nama-nama Desa, pilih Desa

Sipodeceng.

Pilihan pada Desa Sipodeceng akan membawa kita pada halaman Website Desa Sipodeceng.
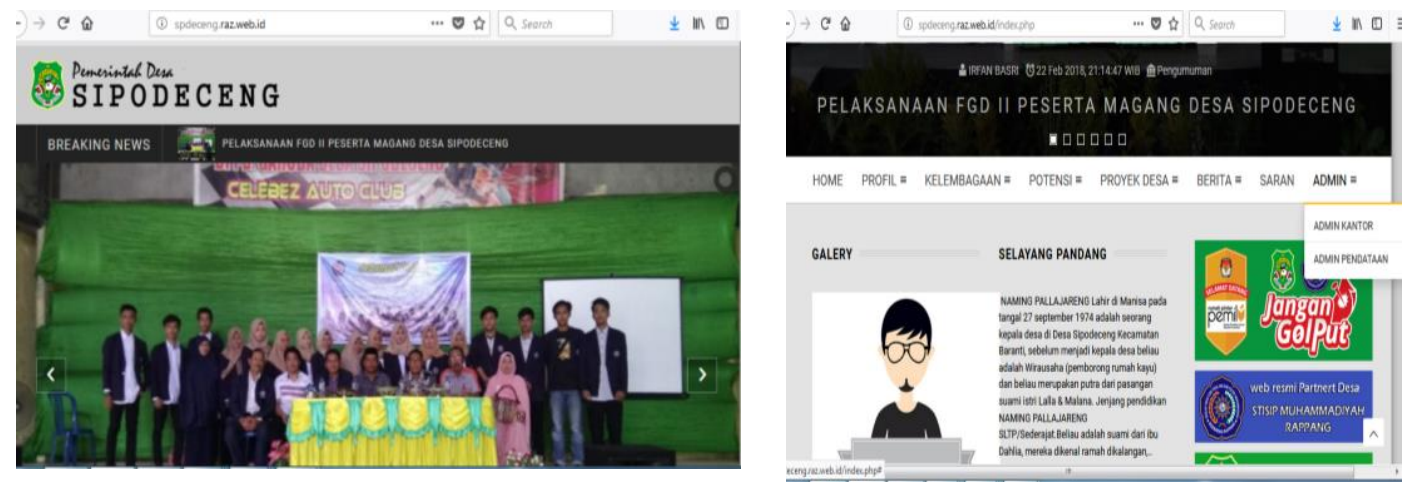

Website Desa Sipodeceng tersebut diatas adalah disain dari bagian IT Stisip Muhammadiyah Rappang. Beberap menu utama akan muncul seperti: Home; profile;

Kelembagaan; Potensi; Proyek Desa; Berita; Saran; Admin 


\section{Registrasi Peserta Magang}

Peserta Magang, adalah mereka yang telah menyelesaikan perkuliahan selama 5 semister. Berdasarkan data dari bagian akademik kemudian dihimpun oleh Lembaga Kerjasama dan kantor Urusan Internasional (LK2UI), maka ditetapkan nama-nama Mahasiswa yang ditempatkan di Posko Sipodeceng di di registrasi dalam webside Sipodeceng sebagai mahasiswa yang bertugas dalam proses pendataan:

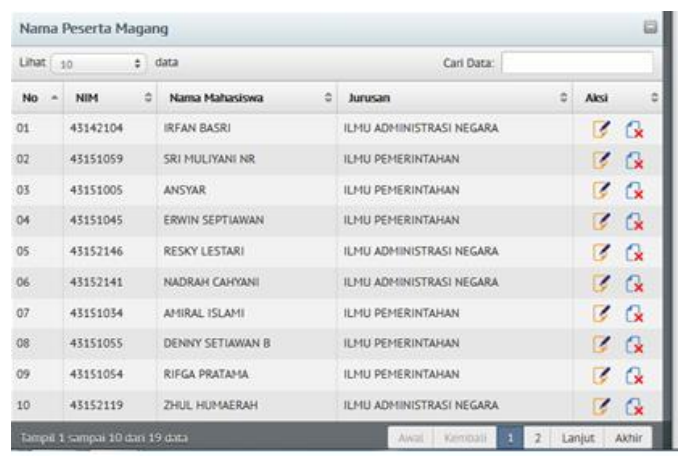

Mahasiswa tampil dalam web hal 1/2

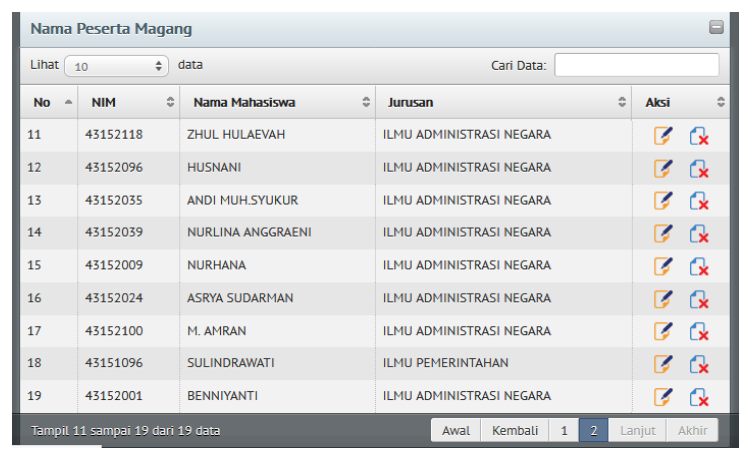

Mahasiswa tampil dalam web hal 2/2

Untuk memastikan pelaksanaan pendataan oleh peserta Magang ditetapkan 4 orang dosen pembimbing dan 4 :

\section{FGD (Forum Group Discussiuon)}

Kegiatan FGD dilaksanakan pada 27 Januari 2018 dihadiri oleh seluruh Kepala Desa termasuk Bapak Naming Pallajareng sebagai Kepala Desa Sipodeceng dilaksanakan di Aula Stisip Muhammadiyah Rappang lantai 1 dengan Pembicara Utama, Ketua Stisip didampingi oleh Tim Tehnis dari IT dan LK2UI.

Pada kegiatan ini, Ketua Stisip menjelaskan tentang tujuan utama kegiatan ini dan tidak ada hubungannya dengan pelaksanaan PILKADA SERENTAK 2018, dimana Kabupaten Sidenreng Rappang diikuti oleh 2 pasangan Calon Kepala Daerah. Dan 
meminta kepada Kepala Desa untuk membantu proses pelaksanaan data di Lapangan. Juga disepakati perlunya Surat resmi dari Stisip ke Sekretariat Daerah Kabupaten Sidenreng rappang dan Surat Tugas dari Kepala Desa kepada Mahasiswa yang mendata di lapangan.

\section{Pelaksanaan Pendataan di Lapangan}

Kegiatan pendataan dilakukan oleh Mahasiswa Magang yang dibagi berdasarkan 3 Dusun yaitu Dusun Dea, Padacengga dan Dusun Bunginge.

Pendataan di lapangan dilakukan dengan mendatangi rumah penduduk kemudian kondisi dan potensi desa langsung diinput ke dalam webside Desa Sipodeceng. Dimulai dengan mengisi User dan pasword Admin yang telah ditentukan.

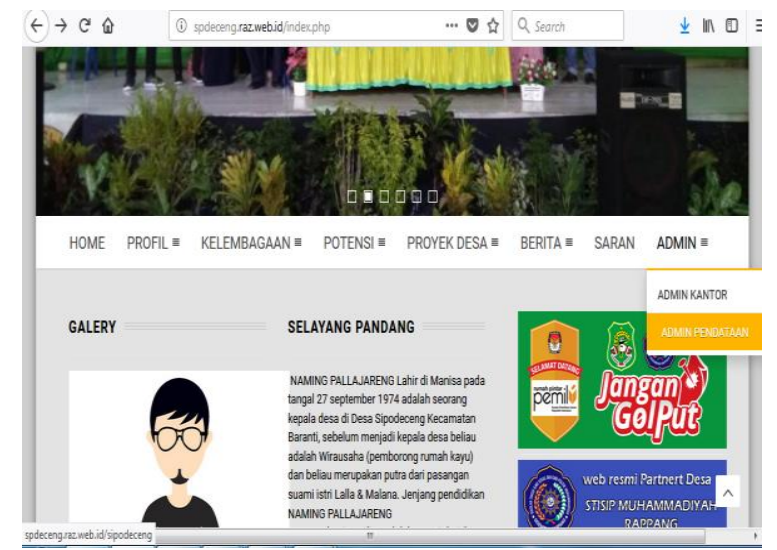

Tampilan menu utama dalam web

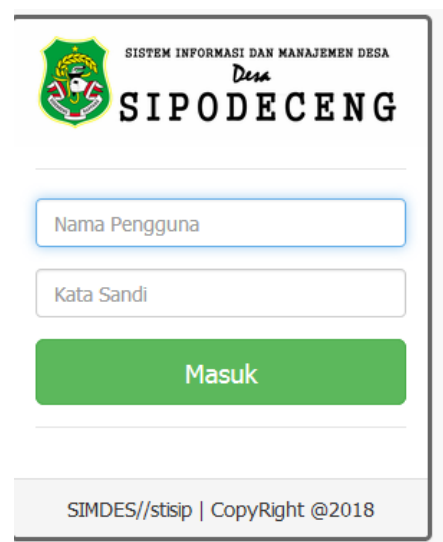

Masuk ke
menu Admin,
pilih Adm
Pendataan,
kemudian isi
data Pengguna
dan Kata Sandi.

Kotak isian Pengguna

Saat Mahasiswa magang berdialog dengan Kepala keluarga, petugas magang yang lain melakukan entry data, ke dalam fitur tersedia dalam web desa. 


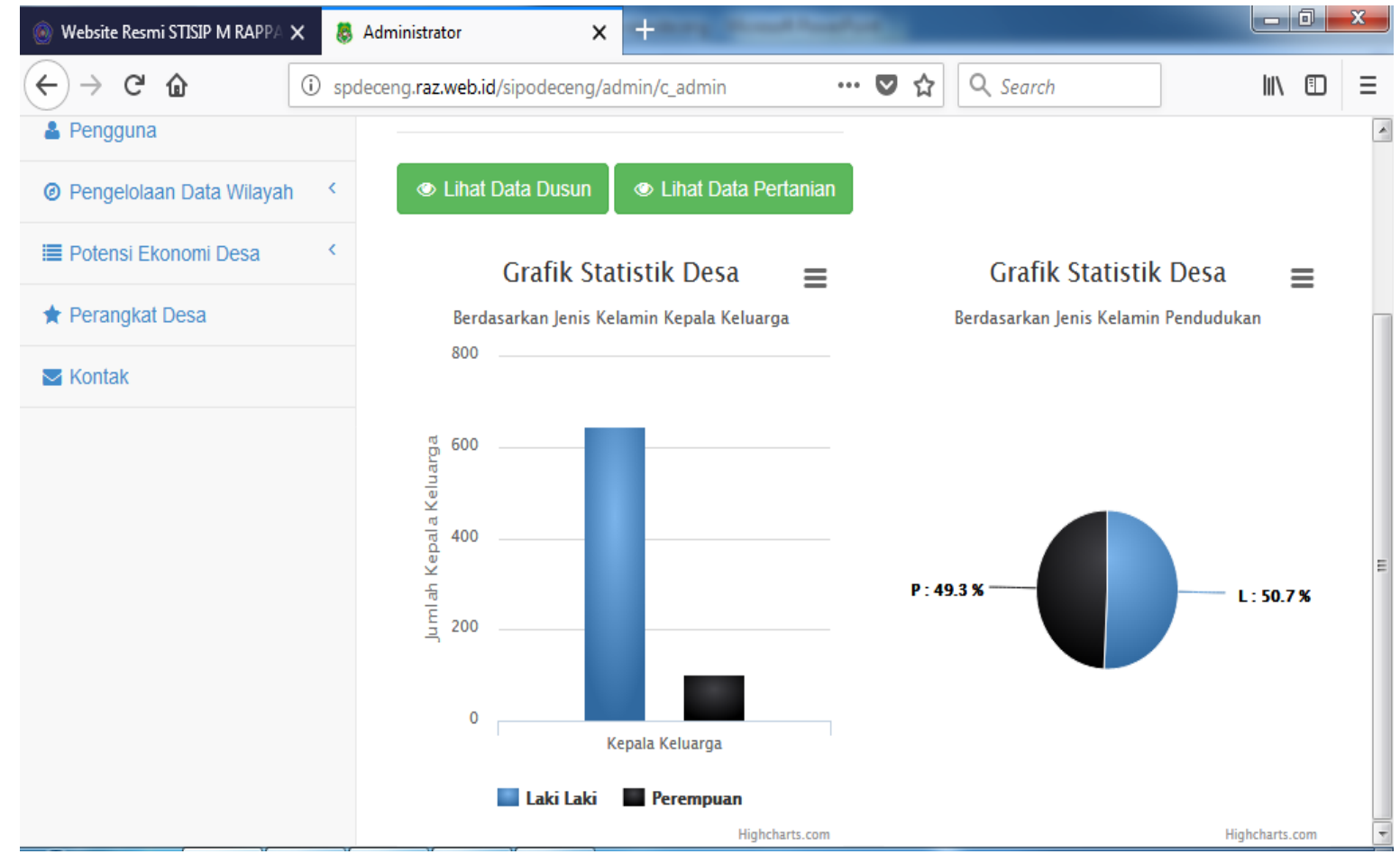

Grafik statistik Desa dalam bentuk diagram batang dan lingkaran, kondisi per dusun dan data pertanian dapat dibuka satu persatu untuk melihat hasilnya . Data pengelolaan wilayah, potensi desa dan Perangkat desa juga dapat diisi ataupun diperbaharui.

Untuk menambahkan data contoh, pertanian dapat dilakukan dengan membuka data pertanian pada Potensi desa, kemudia klik Add, maka data baru dapat diinput pada kotak isian seperti pada gambar kanan bawah.
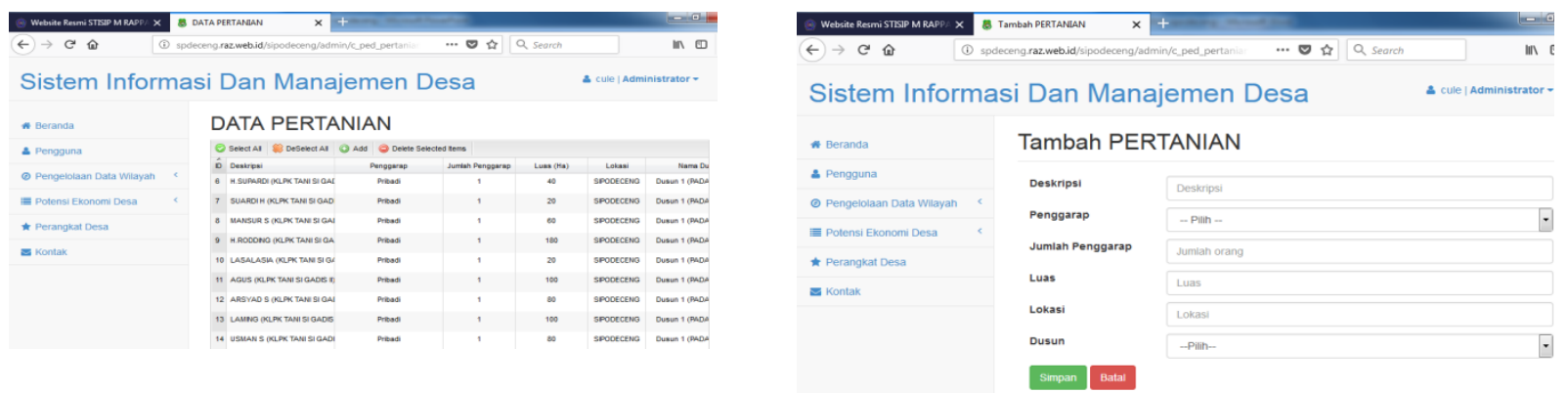


\section{Singkronisasi dan Publish}

Hasil entry data, dimonitoring oleh IT Stisip kemudian dilakukan singkronisasi dan monitoring data berdasarkan tampilan yang muncul di masing-masing desa. Tahapan ini sebagai kontrol pada proses pendataan. Sehingga pihak Pengelola kegiatan magang dapat melakukan monitoring atas progres pencapaian pendataan di lapangan oleh setiap Desa. Setelah proses pendataan mencapai $80 \%$, setiap desa mengadakan FGD ke 2 di lokasi masing-masing. Untuk desa Sipodeceng pelaksanaan FGD ke-2 dilaksanakan pada hari sabtu tanggal 17 Februari 2018 di Kantor Desa lama dengan menghadirkan Kepala Desa dan perangkatnya, Ketua Stisip bersama dengan Tim Magang (LK2UI \& IT), Dosen Pembimbing serta masyarakat.

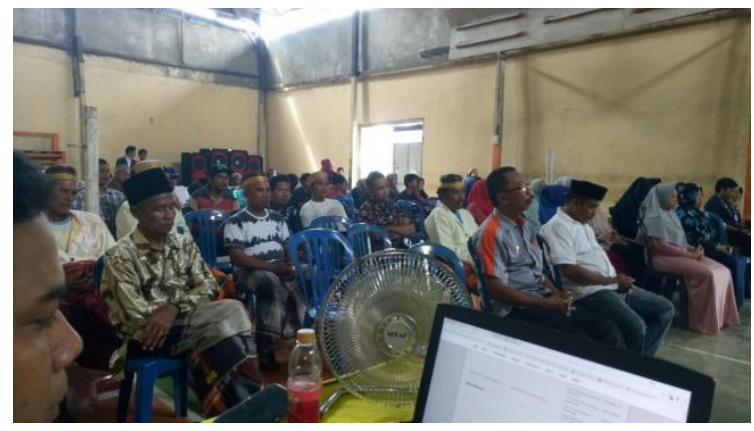

Warga Sipodeceng antusias mengikuti FGD

ke2, 17 Februari 2018 dan mendengarkan

Progress Magang dari Ketua Stisip

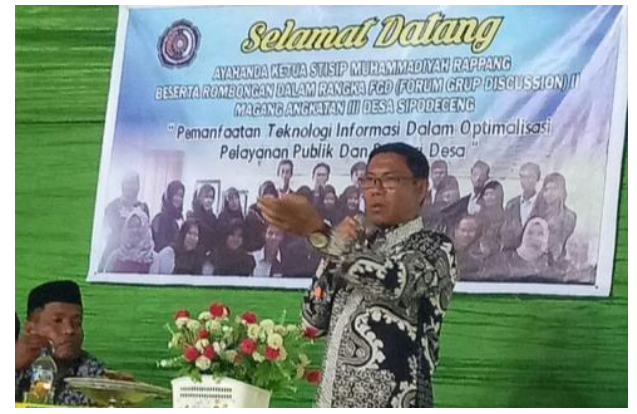

Ketua Stisip menjelaskan pencapaian $80 \%$ dan output magang dihadapan kepala desa dan masyarakat.

\section{Serah Terima Webside Desa}

Setelah pelaksanaan Penarikan mahasiswa magang Desa Sipodeceng pada hari jumat 2 Maret 2018 oleh Ketua Stisip Muhammadiyah Rappang, ynag disaksikan oleh Kepala Desa, Dosen Pembimbing dan masyarakat. Maka seluruh rangkaian kegiatan di lapangan dinyatakan selesai, kemudian dilanjutkan kembali dengan kegiatan dikampus. 
Secara keseluruhan Kegiatan Penarikan Magang Stisip Muhammadiyah Rappang untuk 10 desa daltisip, kegiatan ini kemudian dilanjutkan dengan serah terima Web dari Ketua Stisip kepada 10 Kepala Desa, yang kemudian juga dilakukan serahterima Petugas Admin dari IT Stisip ke masing-masing Operator Desa.

\begin{tabular}{|c|c|c|c|}
\hline$\leftarrow) \rightarrow$ C & \multicolumn{3}{|c|}{ (i) spdeceng.raz.web.id/administrator/media.php?mo $\quad \cdots \bullet \boldsymbol{v}$} \\
\hline \multicolumn{4}{|c|}{ D belum dibaca } \\
\hline MENU UTAMA & $\nabla$ & \multicolumn{2}{|c|}{ IDENTITAS WEBSITE } \\
\hline MODUL BERITA & $\nabla$ & \multirow{2}{*}{$\begin{array}{l}\text { Nama Website } \\
\text { URL }\end{array}$} & Sipodeceng \\
\hline MODUL VIDEO & 7 & & http://spdeceng.stisipmrappang.ac.id \\
\hline MIOUOL VIUEO & 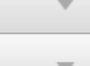 & & $\begin{array}{l}\text { - Apabila di-onlinekan di web hosting, ganti URL dengan URL website anda. } \\
\text { contoh: http://stisipmrappang.acid }\end{array}$ \\
\hline WIVUOL INLAIV & 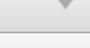 & \multirow[t]{2}{*}{ Social } & \# \\
\hline MODUL WEB & $\nabla$ & & - contoh: \#, \#, dll \\
\hline MODUL USER & $\nabla$ & Meta Deskripsi & Menyajikan berita terbaru, tercepat, dan terpercaya seputar Desa Sipodeceng \\
\hline & & Meta Keyword & Selamat datang di website resmi Desa Sipodeceng I dengan motto SIPAKATAU: \\
\hline & & Email & desa_sipodeceng@yahoo.com \\
\hline & & No. Telp/HP & 085396607750 \\
\hline & & Google Maps & https://www.google.com/maps/embed?pb=!1m18!1m12!1m3!1d31846.709411081 \\
\hline & & No. Rekening & - \\
\hline & & Gambar Favicon & 3 \\
\hline
\end{tabular}

Website ini selanjutnya dikelola oleh desa. Dan pihak IT Stisip bersama dengan dosen Pembimbing tetap akan memberikan supervisi
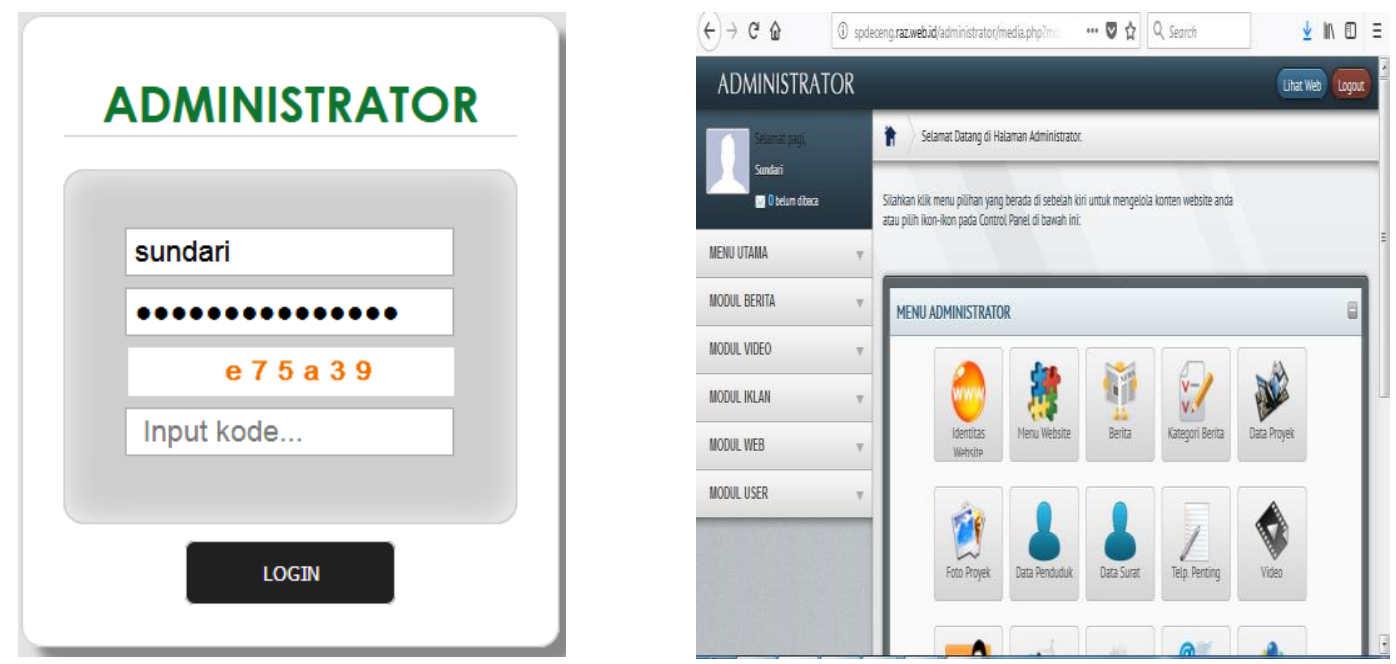
Website ini selanjutnya dikelola oleh desa. Dan pihak IT Stisip bersama dengan dosen Pembimbing tetap akan memberikan supervisi untuk mengoptimalkan penggunaan tehnologi informasi dalam rangka membantu Pemerintah Desa utanya dalam dalam memberikan pelayanan berbasis IT kepada Publik.

\section{Bantuan Peralatan}

Dalam pelaksanaan kegiaatan ini kami menggunakan beberapa peralatan dan bahan antara lain :

1. Laptop

2. Alat pendataan

3. Hand phone berbasis android

\section{Indikator Keberhasilan}

Ukuran yang digunakan untuk mengukur keberhasilan program ini adalah tersedianya website Desa yang dapat menjadi sumber informasi ter-aktual dan akurat serta dapat diakses dengan mudah oleh masyarakat ataupun stake holder yang terkait dengan kegiatan ekonomi di Desa Sipodeceng.

\section{E. Evaluasi Kegiatan}

Evaluasi dilakukan dalam program ini terlaksana secara sistematis sebagai berikut:

- Evaluasi Perencanaan (Proposal)

- Evaluasi Organisasi (Kerjasama) 
- Evaluasi Pelaksanaan (Implementasi Program)

- Evaluasi Output (hasil Program)

- Evaluasi Outcame

F. Keberlanjutan Dari Program Magang Yang Dilaksanakan

Adapun tindak lanjut yang diharapkan dari program ini yaitu:

1. Penyediaan informasi berbasis IT.

2. Pengembangan Pelayanan administrasi dalam bentuk layanan berbasis IT

\section{G. Hambatan-Hambatan Yang Dihadapi Di Lapangan}

1. Jaringan Informasi Tehnologi belum merata ke pelosok kadang mengalami gangguan jaringan sehingga menyulitkan saat pendataan di lapangan

2. Ketersediaan perangkat IT di kantor desa, sehingga Mahasiswa Magang banyak melakukan maintenance data di luar kantor. 
IV

\section{PENUTUP}

\section{A. Simpulan}

Pelaksanaaan program Magang dengan tema "Pemamfaatan teknologi informasi dalam optimalisasi pelayanan publik dan potensi desa”. Mendapat sambutan positif dari Aparat Desa dan masyarakat dengan turut aktif dalam membantu proses pendataan, kegiatan ini memberikan motivasi tersendiri kepada masyarakat untuk belajar dan mengenal banyak bentuk pelayanan berbasis tehnologi informasi. Hal ini akan menjadi modal baik bagi Pemerintah Desa untuk membawa Desa Sipodeceng menuju desa yang lebih maju .

\section{B. Saran}

Diharapkan tetap ada monitoring dan pembinaan berkelanjutan terhadap implementasi kegiatan ini, sehingga output kegiatan tetap dapat memberikan nilai tambah kepada masyarakat Desa Sipodeceng serta terjalin sinergitas dengan bentuk program pengabdian Stisip Muhammadiyah Rappang yang lain dan sudah berjalan. 


\section{DAFTAR PUSTAKA}

1) Ali, Akhwan. (2017). Pengaruh Teknologi Pertanian Terhadap Produktivitas Hasil Panen Padi di Kecamatan Maritengngae Kabupaten Sidenreng Rappang. AKMEN Jurnal Ilmiah. Volume 14 Issue 3. https://e-jurnal.stienobelindonesia.ac.id/index.php/akmen/article/view/88

2) Bartono dan Ruffino. (2010). Tata Boga Industri. Yogyakarta: Andi.

3) Mustanir, A. \& Razak, M.R.R. (2017). Nilai Sosial Budaya Pada Partisipasi Masyarakat EtnikTowani Tolotang Dalam Musyawarah Rencana Pembangunan. Prosiding Konferensi Nasional Ke- 6 Asosiasi Program Pascasarjana Perguruan Tinggi Muhammadiyah 'Aisyiyah (APPPTMA).

4) Mustanir, A.; Justira, Nur.; Sellang, K.; Muchtar, Andi Ilham. (2018). Democratic Model On Decision-Making At Deliberations Of Development Planning. DOI: 10.13140/RG.2.2.12159.66727 https://www.researchgate.net/publication/330090538_Democratic_Model_On_Decisi on-Making_At_Deliberations_Of_Development_Planning. ISBN 978-602-6309-44-2.

5) Panduan Pengabdian Masyarakat STISIP Muhammadiyah Rappang. 2017.

6) Prijono, O.S. \& Pranarka, A.M.W. (1996). Pemberdayaan. Konsep Kebijakan dan Impelementasi, Jakarta. CSIS.

7) Razak, M.R.R. (2017). Penguatan Lembaga Desa Berbasis Kewirausahaan dengan Pemanfaatan Koran Bekas pada Kerajinan Tangan Masyarakat Sipodeceng. KKLPXVI-Pengabdian 2017 Lembaga Pengabdian Masyarakat Stisip Muhammadiyah Rappang. DOI: 10.13140/RG.2.2.22797.79841. https://www.researchgate.net/publication/331088645_Penguatan_Lembaga_Desa_Ber basis_Kewirausahaan_dengan_Pemanfaatan_Koran_Bekas_pada_Kerajinan_Tangan_ Masyarakat_Sipodeceng

8) Sitonda, R. \& Razak, M.R.R. (2018). Konsep Perencanaan Pembangunan Partisipatif di Daerah. Prosiding Konferensi Nasional Ke- 7 Asosiasi Program Pascasarjana Perguruan Tinggi Muhammadiyah 'Aisyiyah (APPPTMA).

9) http://www.gurupendidikan.co.id/10-pengertian-teknologi-informasi-menurut-paraahli/

10) http://www.komunikasipraktis.com/2015/04/komunikasi-massa-pengertian.html

11) https://ahlikomunikasi.wordpress.com/2012/11/01/george-gerbner-fungsi-mediamassa/

12) https://www.scribd.com/doc/23817594/Thomas-R-Dye-Anderson-Jones-Dll. 


\section{Lampiran Dokumentasi Photo Kegiatan}

\section{Kegiatan Pendataan di Lapangan}

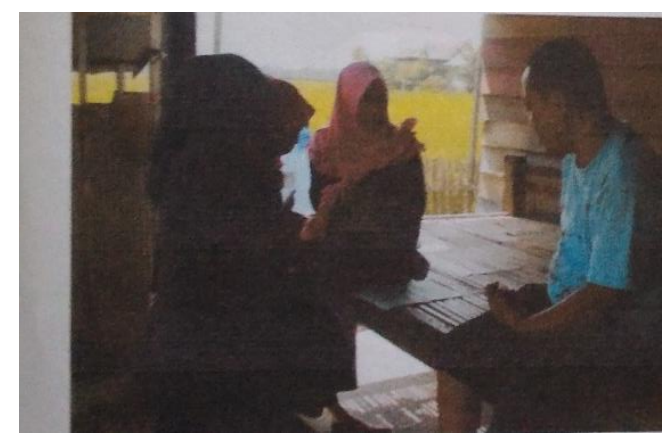

Mendatangi dan mendata warga di rumah

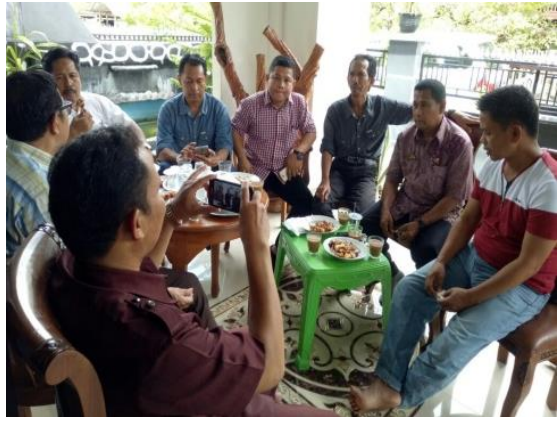

Diskusi dosen pembimbing yang intens

\section{Peran aktif Pembimbing dan Kepala Desa dalam sosialisasi}

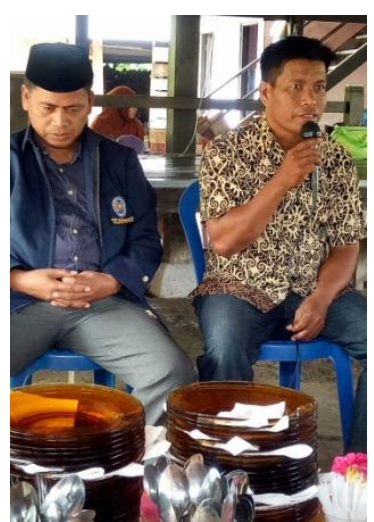

Pa Desa menjelaskan mamfaat magang bagi Desa Sipodeceng

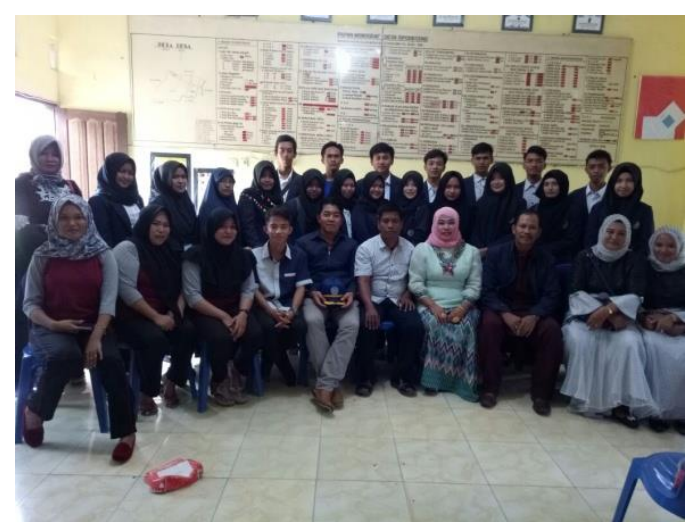

Tim pembimbing, aparat desa dan mahasiswa kompak dalam memperkenalkan pelayanan berbasis IT

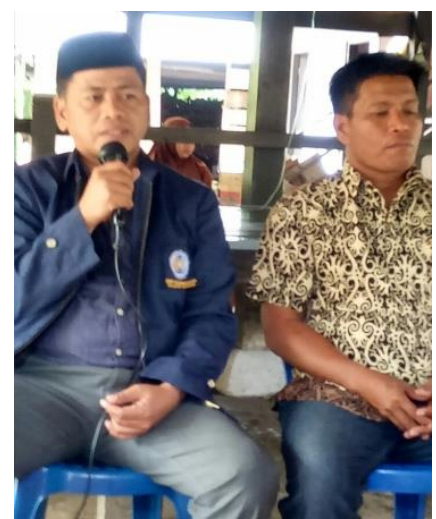

Kord Pembimbing meyakinkan pentingnya IT dalam pelayanan

\section{FGD dan serahterima web Desa dari Stisip ke Kepala Desa}

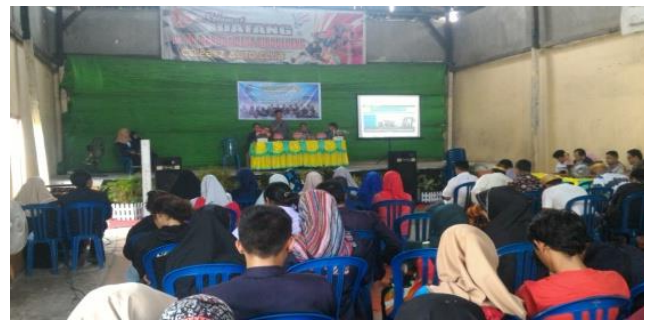

FGD ke2, 17 Feb 2018. Progres $80 \%$ pendataan potensi desa.

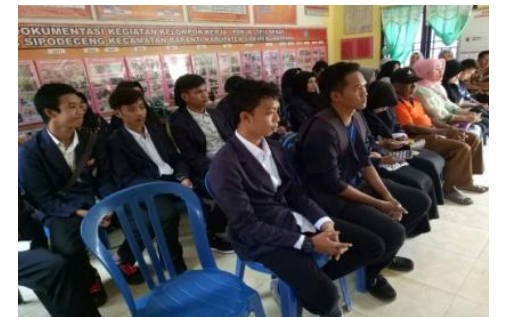

Penarikan serentak mahasiswa Magang

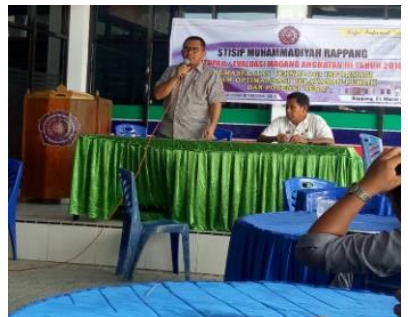

Sambutan ketua LK2UI \& penyerahan web 